\title{
EVALUATION OF MicroRNA-124 EXPRESSION IN RENAL CELL CARCINOMA
}

Çaykara B ${ }^{1}$, Öztürk $\mathrm{G}^{1}$, Alsaadoni $\mathrm{H}^{2}$, Ötünçtemur A ${ }^{3}$, Pençe $\mathrm{S}^{1}$

*Corresponding Author: Güler Öztürk, Ph.D., Department of Physiology, Faculty of Medicine, Istanbul Medeniyet University, 34700 Uskudar, Istanbul, Turkey. Tel.: +90-216-280-2802. Fax: +90216-280-2804. E-mail: gulerturk@yahoo.co.uk

\begin{abstract}
The Wingless/INT (WNT) signaling network has roles in renal cancer development. It was shown that the tumorsuppressor microRNA-124 (miR-124) is associated with the Wnt pathway. Thus, we aimed to measure miR-124 expression levels to evaluate whether it is a prognostic marker or a potential treatment strategy. Thirty tumor and 30 surrounding healthy kidney tissues from the same subjects diagnosed with renal cell carcinoma (RCC), were included in the study. The expression levels of miR-124 were measured with real-time polymerase chain reaction (qPCR) and determined by the $2^{-\triangle \triangle C T}$ method. The Statistical Package for Social Science (SPSS) version 22 program was used for statistical analyses and a $p$ value of 0.05 was considered to be statistically significant. The expression levels of miR-124 was found to be about 3-fold lower in tumors than in healthy tissues ( $p$ 0.001) and decreased expression levels correlated with tumor stage, tumor diameter, body mass index (BMI) and neutrophil values ( $p 0.05$ ). Our results showed that miR-124 expression levels are associated with RCC. MicroRNA-124 may be assessed as a biomarker in prognosis and the restoration of miR-124 expression might be effective in the treatment of RCC.
\end{abstract}

Keywords: Expression; microRNA-124 (miR-124); Renal cell carcinoma (RCC).

\footnotetext{
${ }^{1}$ Department of Physiology, Faculty of Medicine, Istanbul Medeniyet University, Istanbul, Turkey

2 Department of Pathology Laboratory Techniques, Hamidiye Vocational School of Health Services, University of Health Sciences, Istanbul, Turkey

${ }^{3}$ Department of Urology, Okmeydani Training and Research Hospital, Istanbul, Turkey
}

\section{INTRODUCTION}

Renal cell carcinomas (RCCs), the third most common urological cancer, constitute approximately $85.0 \%$ of all parenchymal renal tumors and the highest mortality rate of urological cancer due to more than $40.0 \%$ mortality [1]. There are no early markers for RCCs and cancer cases are usually resistant to radiotherapy and chemotherapy [2]. Renal cell carcinomas with subtypes such as clear cell, papillary type, chromophobe tumors, are highly heterogeneous. Understanding the subtype and pathways involved in RCCs is very important in terms of enabling treatment and early detection [3,4].

MicroRNAs (miRNAs), which play an important role in the control of gene expression, are short-sequence RNA molecules that are encoded by DNA but not converted to proteins. By binding to the messenger RNA (mRNA) of the target gene, they can cause mRNA degradation and translational inhibition $[5,6]$. Studies on microRNAs showed that they can play a role in cancer formation $[7,8]$. Discovering of the role of microRNAs and target genes involved in renal cell carcinoma is important in that it can allow the classification of subtypes, selection and identification of future treatment options.

Long et al. [9] reported that microRNA-124 (miR-124) targets frizzled (FZD) receptor protein-5 (FZD-5) in the Wingless/INT (WNT) signaling network and also acts as FZD5 small interfering RNA (siRNA) in P-glycoprotein (Pgp) expression in Caki-2/Doxorubicin (DOX) cell culture and shows inhibitory effects. Thus, miR-124 is thought of as a promising strategy for multidrug resistance due to the effects on Pgp [9]. Targeting WNT signaling, which has roles in embryonic development and renal cancer development, inhibits the growth or killing of cancer cells [10]. For this reason, we analyzed the expression levels of miR-124 that functions as a tumor suppressor $[11,12]$ in RCC carcinoma tissues to evaluate whether it is a prognostic marker or a potential treatment strategy which may be targeted. 


\section{MATERIALS AND METHODS}

Tissue Collection. Ethical approval was obtained by consulting the Istanbul Faculty of Medicine, Ethics Committee [Approval No. 2016/1428]. Tumor and nontumor tissue samples obtained with surgical procedures from RCC diagnosed patients in the Okmeydani Training and Research Hospital, Istanbul, Turkey. Tissues were stored at $-80{ }^{\circ} \mathrm{C}$ until total RNA isolation was performed. Tumor tissues from 30 patients with RCC were included in the tumor group. The healthy surrounding tissues of same patients also formed the control group.

Total RNA Isolation and miR-124 Expression Analysis. Total RNA isolation was performed according to the protocol through the QIAzol Lysis Reagent (Qiagen $\mathrm{GmbH}$, Hilden, Germany) using $\sim 30 \mathrm{mg}$ sections of RCC and healthy surrounding tissues. Analysis of miR-124 and U6 from total RNA was performed with 'hsa-mir-124 realtime-polymerase chain reaction (q-PCR) Detection and U6 Calibration Kit' (Cohesion Bioscience, London, UK). The reverse transcriptase PCR (RT-PCR) was performed in $20 \mu \mathrm{L}$ total volume with $2 \mu \mathrm{L}$ of $100 \mathrm{ng} \mathrm{RNA}, 4 \mu \mathrm{L}$ of $5 \times$ RT Master Mix, $0.75 \mu \mathrm{L}$ of dNTP $(1 \mathrm{nM}), 1.2 \mu \mathrm{L}$ of miR-RT primer, $0.2 \mu \mathrm{L}$ of Moloney murine leukema virus (MMLV) Reverse Transcriptase $(200 \mathrm{U} / \mu \mathrm{L})$ and 11.85 $\mu \mathrm{L}$ of RNAase free $\mathrm{H}_{2} \mathrm{O}$. The PCR mix was incubated for $30 \mathrm{~min}$. at $25^{\circ} \mathrm{C}, 30 \mathrm{~min}$. at $42{ }^{\circ} \mathrm{C}$ and $5 \mathrm{~min}$. at 85 ${ }^{\circ} \mathrm{C}$. Reverse transcriptase products were stored at $-20{ }^{\circ} \mathrm{C}$ until qPCR was performed. The qPCR was performed in a $20 \mu \mathrm{L}$ total volume with $10 \mu \mathrm{L}$ of $2 \times$ RT-PCR Master Mix, $0.4 \mu \mathrm{L}$ of miR specific primer set $(10 \mu \mathrm{M}), 2 \mu \mathrm{L}$ of ROX reference dye, $1 \mu \mathrm{L}$ of PCR enhancer, $0.2 \mu \mathrm{L}$ of Taq DNA polymerase $(5 \mathrm{U} / \mu \mathrm{L}), 2 \mu \mathrm{L}$ of miRNA RT product $4.4 \mu \mathrm{L}$ of RNAase free $\mathrm{H}_{2} \mathrm{O}$. The real-time PCR mix was incubated for $3 \mathrm{~min}$. at $95^{\circ} \mathrm{C}$, followed by the 40 cycles of 12 seconds at $95^{\circ} \mathrm{C}$ and 40 seconds at $62^{\circ} \mathrm{C}$.

Statistical Analyses. MicroRNA-124 expression levels were calculated as $2^{-\Delta \Delta C T}[13]$. The Statistical Package for Social Science (SPSS) version 22 (IBM Corporation, Armonk, NY, USA) program was used for statistical analyses. The distribution of the data was analyzed with Shapiro Wilk test. Wilcoxon rank sum and Spearman's Rho test were used for the analysis of determined data that did not show a normal distribution. The data were expressed as mean \pm standard deviation (SD) and a $p$ value of 0.05 was considered to be significant.

\section{RESULTS}

The ages of the patients included in the study were 58.7 \pm 10.26 , while height, weight and body mass index (BMI) values were $172.17 \pm 5.62,81.03 \pm 7.69,27.52 \pm 2.97$, re- spectively. The values of the patients' data are given in Table 1 as mean \pm SD. The mean diameter of tumors was $6.05 \pm$ $2.83 \mathrm{~cm}$. The minimum tumor diameter was $2.5 \mathrm{~cm}$ and the maximum tumor diameter was $13 \mathrm{~cm}$. The diameters of 15 tumors was smaller than $5 \mathrm{~cm}$, diameters of 13 tumors were between 5 and $10 \mathrm{~cm}$, and the diameters of two tumors were larger than $10 \mathrm{~cm}$. According to the tumor-node-metastasis (TNM) classification system, 19 tumors were stage I (T1), six tumors were stage II (T2) and five tumors were stage III (T3). According to the Fuhrman nuclear grading system, three tumors were grade 1, 17 tumors were grade 2, eight tumors were grade 3 and two tumors were grade 4 .

When both miR-124 and U6 expression levels were calculated for the tumor and healthy surrounding tissues according to the $2^{-\triangle \triangle C T}$ method, it was observed that miR$124 \mathrm{had}$ decreased expression levels in 28 tumor tissues and partially increased expression levels in two tumor tissues. The values of $\Delta \mathrm{CT}$ and $2^{-\Delta \mathrm{CT}}$ in the control and tumor groups determining $p$ values are given in Table 2. The mean $\Delta$ CT values of the tumor and control groups were $9.3 \pm 2.24$ and $6.73 \pm 1.95$, respectively. The difference in expression analysis between tumor and control tissues was found to be statistically significant $(Z=-4.453, p 0.001)$ and fold change values were 0.356 (Table 2). As a result, miR-124 had about 3-fold lower expression levels in RCC tissues (Figure 1).

Table 1. The clinical parameters of patients.

\begin{tabular}{|l|r|c|c|}
\hline Parameters & Mean \pm SD & Minimum & Maximum \\
\hline Age $($ years $)$ & $58.70 \pm 10.26$ & 39 & 83 \\
\hline Height $(\mathrm{cm})$ & $172.17 \pm 5.62$ & 163 & 185 \\
\hline Weight $(\mathrm{kg})$ & $81.03 \pm 7.69$ & 60 & 100 \\
\hline BMI $\left(\mathrm{kg} / \mathrm{m}^{2}\right)$ & $27.52 \pm 2.97$ & 20.8 & 36.7 \\
\hline Waist circumference $(\mathrm{cm})$ & $104.50 \pm 6.29$ & 95 & 117 \\
\hline Total cholesterol $(\mathrm{mg} / \mathrm{dL})$ & $196.10 \pm 35.35$ & 139 & 257 \\
\hline Triglycerides $(\mathrm{mg} / \mathrm{dL})$ & $159.07 \pm 36.20$ & 98 & 225 \\
\hline HDL $(\mathrm{mg} / \mathrm{dL})$ & $43.40 \pm 3.14$ & 36 & 49 \\
\hline LDL $(\mathrm{mg} / \mathrm{dL})$ & $125.10 \pm 25.98$ & 68 & 172 \\
\hline Neutrophils $\left(\right.$ cells $\left./ \mathrm{mm}^{3}\right)$ & $5.07 \pm 1.05$ & 3.14 & 6.82 \\
\hline Lymphocytes $\left(\right.$ cells $\left./ \mathrm{mm}^{3}\right)$ & $1.64 \pm 0.18$ & 1.32 & 1.99 \\
\hline
\end{tabular}

BMI: body mass index; HDL: high density lipoprotein;

LDL: low density lipoprotein.

Table 2. The cycle threshold (Ct) values obtained for miR-124.

\begin{tabular}{|l|c|c|}
\hline & $\begin{array}{c}\text { Tumor } \\
\text { Tissues }^{\text {a }}\end{array}$ & $\begin{array}{c}\text { Healthy Surrounding } \\
\text { Tissues }^{b}\end{array}$ \\
\hline$\Delta \mathrm{CT}$ & $9.30 \pm 2.24$ & $6.73 \pm 1.95$ \\
\hline$\Delta \Delta \mathrm{CT}$ & & 2.72 \\
\hline $2^{-\Delta \Delta \mathrm{CT}}$ & & 0.356 \\
\hline$p$ Value & & $<0.001$ \\
\hline
\end{tabular}

a Tumor group.

${ }^{\mathrm{b}}$ Control group. 
Table 3. The comparison of miR-124 expression in tumor and control groups with patient parameters.

\begin{tabular}{|l|c|c|c|c|}
\hline Group & \multicolumn{2}{|c|}{$\mathbf{2}^{-\Delta \text { CT }}$ (tumor group) } & \multicolumn{2}{c|}{$\mathbf{2}^{-\Delta C T}$ (control group) } \\
\hline & $r$ Value & $p$ Value & $r$ Value & 0.63 \\
\hline Age & -0.14 & 0.47 & -0.09 & 0.99 \\
\hline Height & 0.89 & 0.32 & -0.067 & 0.72 \\
\hline Weight & -0.081 & 0.67 & -0.06 & 0.75 \\
\hline Body mass index & -0.41 & $\mathbf{0 . 0 2 3}$ & 0.23 & 0.23 \\
\hline Waist circumference & -0.088 & 0.64 & -0.085 & 0.65 \\
\hline Total cholesterol & -0.33 & 0.07 & 0.09 & 0.64 \\
\hline Triglycerides & -0.17 & 0.37 & -0.21 & 0.26 \\
\hline High density lipoprotein & -0.05 & 0.79 & -0.08 & 0.68 \\
\hline Low density lipoprotein & -0.25 & 0.18 & 0.16 & 0.39 \\
\hline Tumor stage & -0.42 & $\mathbf{0 . 0 2 2}$ & 0.16 & 0.4 \\
\hline Tumor diameter & -0.47 & $\mathbf{0 . 0 0 9}$ & 0.71 & 0.71 \\
\hline Neutrophil & -0.415 & $\mathbf{0 . 0 2 3}$ & 0.23 & 0.22 \\
\hline Lymphocyte & 0.24 & 0.21 & 0.1 & 0.56 \\
\hline Visceral adiposity index & -0.17 & 0.365 & & \\
\hline
\end{tabular}

Table 4. The correlation of miR-124 expression according to tumor stage with patient parameters.

\begin{tabular}{|c|c|c|c|c|c|c|c|c|c|c|c|c|}
\hline \multirow{3}{*}{$\frac{\text { Stage }}{\text { Group }}$} & \multicolumn{4}{|c|}{ T1 } & \multicolumn{4}{|c|}{$\mathrm{T} 2$} & \multicolumn{4}{|c|}{ T3 } \\
\hline & \multicolumn{2}{|c|}{$2^{-\Delta C \mathrm{~T}}$ (tumor) } & \multicolumn{2}{|c|}{$2^{-\Delta \mathrm{CT}}$ (control) } & \multicolumn{2}{|c|}{$2^{-\Delta \mathrm{CT}}$ (tumor) } & \multicolumn{2}{|c|}{$2^{-\Delta \mathrm{CT}}$ (control) } & \multicolumn{2}{|c|}{$2^{-\Delta C \mathrm{~T}}$ (tumor) } & \multicolumn{2}{|c|}{$2^{-\triangle \mathrm{CT}}$ (control) } \\
\hline & $r$ Value & $p$ Value & $r$ Value & $p$ Value & $r$ Value & $p$ Value & $r$ Value & $p$ Value & $r$ Value & $p$ Value & $r$ Value & $p$ Value \\
\hline $\operatorname{BMI}\left(\mathrm{kg} / \mathrm{m}^{2}\right)$ & -0.3 & 0.212 & 0.23 & 0.34 & -0.54 & 0.27 & -0.43 & 0.4 & -0.9 & 0.037 & -0.9 & 0.037 \\
\hline Tumor dia $(\mathrm{cm})$ & -0.45 & 0.055 & 0.07 & 0.78 & 0.81 & 0.05 & -0.058 & 0.91 & -0.6 & 0.28 & 0.1 & 0.87 \\
\hline $\mathrm{TC}(\mathrm{mg} / \mathrm{dL})$ & -0.56 & 0.012 & -0.056 & 0.82 & -0.48 & 0.33 & 0.54 & 0.26 & -0.5 & 0.39 & -0.9 & 0.037 \\
\hline $\mathrm{NP}\left(\right.$ cells $\left./ \mathrm{mm}^{3}\right)$ & -0.47 & 0.04 & -0.21 & 0.4 & 0.26 & 0.62 & 0.03 & 0.96 & -0.1 & 0.87 & 0.4 & 0.505 \\
\hline
\end{tabular}

BMI: body mass index; Tumor dia: tumor diameter; TC: total cholesterol; NP: neutrophil.

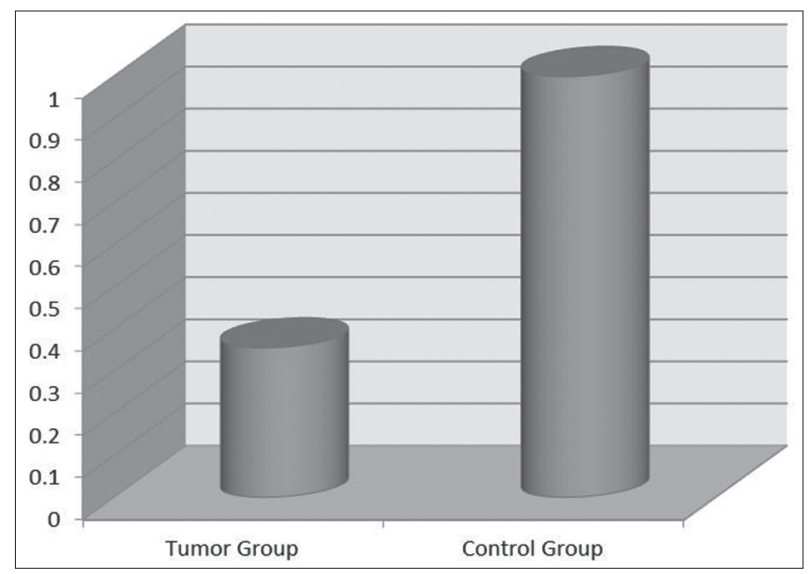

Figure 1. The expression levels of miR-124 in tumor and control groups.

When the expression levels of miR-124 $2^{-\Delta \mathrm{CT}}$ of tumor and control groups were examined, the expression levels of the tumor group showed a significantly negative correlation with BMI ( $p=0.023, r=-0.413)$, tumor stage ( $p=0.022$, $r=-0.417)$, tumor diameter $(p=0.009, r=-0.468)$ and neutrophil count ( $p=0.023, r=-0.415)$. As the tumor stage, diameter, BMI and neutrophil values increased, it was observed that miR-124 was expressed at lower levels (Table 3).

According to the tumor stage, the tissues were divided into three different groups and the expression of miR-124 and all other parameters were evaluated according to Spearman's Rho test. Expression of miR-124 in tumor tissues at T1 stage was negatively correlated with total cholesterol and neutrophil values $(r=-0.563, p=0.012 ; r=-0.476, p$ $=0.04$, respectively). Positive correlations were observed between the expression of miR-124 and tumor diameter $(r$ $=0.812, p=0.05)$ in tumor tissues at the T2 stage. The expression of miR-124 and total cholesterol levels in healthy surrounding kidney tissues of patients at the T3 stage were found to be significantly negative correlated $(r=-0.9, p=$ $0.037)$. Negative correlation was found between BMI and miR-124 expression both in tumor and control tissues in the T3 stage $(r=-0.9, p=0.037)$. There was no statistically significant correlation between age, weight, waist circumference, triglyceride, high density lipoprotein (HDL), low density lipoprotein (LDL), lymphocyte and visceral adipocyte index (VAI) levels and miR-124 expression levels separated by tumor stages (Table 4). 


\section{DISCUSSION}

We observed that miR-124 had a decreased expression in the tissues of renal cell carcinoma than healthy surrounding tissues in our study ( $p$ 0.001). Decreased expression levels of miR-124 were found in 28 tumor tissues and partially increased expression levels in two tumor tissues. The mean $\Delta \mathrm{CT}$ values of the tumor and control groups were $9.30 \pm 2.24$ and $6.73 \pm 1.95$, respectively. It was observed that miR-124 was expressed about 3-fold less in the RCC tissues than in control tissues. The expression levels of miR-124 in RCC tissues were negatively correlated with BMI ( $p=0.023, r=-0.413)$, tumor stage ( $p=0.022, r=-0.417)$, tumor diameter $(p=$ $0.009, r=-0.468)$ and neutrophil count $(p=0.023, r=$ -0.415 ). In other words, as the tumor stage, diameter, BMI and neutrophil values increased, it was seen that miR-124 was expressed at lower levels.

It was reported that DOX and vinblastine (VBL) resistant Caki-2 cells had increased Fzd5 in WNT signaling network, Pgp levels and decreased miR-124 expression levels. When Caki-2/DOX cells were treated with miR-124 mimetics, cells were found to be undergoing apoptosis. It has been suggested in the study that the FZD5/protein kinase $\mathrm{C}$ (PKC) signal is responsible for Pgp and elevated cancer cell survival, and this effect can be prevented by miR-124 function [9]. It was reported that the expression levels of miR-124-3p decreased during the $S$ phase of cell cycle and that contributes to aggressive/meta-static behaviors of clear cell RCC [14]. Gebauer et al. [15] found tumor-specific hypermethylation of miR-124-3p in clear cell RCC and suggested miR-124-3p as an independent prognosticator. We concluded that the expression of miR-124 in RCC tissues decreases in accordance with these studies.

The relationship of the renal system and miR124 was also established. Sõber et al. [16] showed that miR-124 suppresses 1.5 -fold the 3' untranslated region (3'UTR) reporter activity of the mineralocorticoid receptor gene, nuclear receptor subfamily 3 , group $\mathrm{C}$, member 2 (NR3C2), playing a role in renal water and salt balance regulation. Another study found that hypoxia-induced cell migration is prevented by miR-124 overexpression in renal epithelial cells [17]. However, the decreased expression levels of miR-124 in the nasopharyngeal carcinoma (NPC) cell lines (5-8 F, 6-10B, CNE1, CNE2, HONE-1, C666-1 and Sune-1) were reported in the study of Peng et al. [18]. In that study, the expression levels of miR-124 in tumor stage I was found higher than tumor stage II-IV and miR-124 expression was found negatively correlated with tumor stages. Moreover, miR-124 expression was found to be lower in tumors had distant metastasis [18]. In another study, the expression levels of miR-124 were observed to be lower in the metastatic group than the lymphatic node group of the breast cancer tissues. According to the TNM classification, it was reported that the level of miR-124 was lower in patients with advanced stages of breast cancer [19]. Furthermore, miR-124 expression levels were reported 10 -fold lower in medulloblastoma [20]. Expression of miR-124 was decreased significantly in three different glioma samples and miR-124 expression levels was lower in high grade (III and IV) tumors and correlated with glioma malignancy [21]. Similarly, in our results, we found the expression of miR-124 decreased as the diameter and size of the tumors increased. The decrease in expression of miR-124 may stem from the silencing of this tumor supressor gene in the high grade tumors.

In conclusion, there is limited literature on miR-124 and RCC relation. As a result of our experiments, we found that miR-124 expression levels decreased in RCC; we think that miR-124 can be used as a biomarker in RCC. The relationship between altered miR-124 expression levels, tumor stages and metastasis, suggesting that miR-124 may be effective in prognoses. Furthermore, the restoration of miR-124 expression may be effective in the treatment of RCC. Our results should be supported by further clinical trials and cell culture experiments showing the treatment effects of miR-124 in RCC.

Declaration of Interest. The authors report no conflicts of interest. The authors alone are responsible for the content and writing of this article.

\section{REFERENCES}

1. Campbell SC, Lane BR. Malignant renal tumors. In: Wein AJ, Kavoussi LR, Novick AC, Partin AW, Peters CA, editors. Campbell-Walsh Urology, 9th ed. (E-dition). Philadelphia, PA, USA: W.B. Saunders, 2011: 1413-1474.

2. Pécuchet N, Fournier LS, Oudard S. New insights into the management of renal cell cancer. Oncology. 2013; 84(1): 22-31.

3. De Luca A, Carotenuto P, D'Alessio A, Normanno N. Molecular biology of renal-cell carcinoma. Eur J Cancer Suppl. 2008; 6(14): 30-34.

4. Singer EA, Gupta GN, Marchalik D, Srinivasan R. Evolving therapeutic targets in renal cell carcinoma. Curr Opin Oncol. 2013; 25(3) :273-280.

5. Ambros V. The functions of animal microRNAs. Nature. 2004; 431(7006): 350-355.

6. Bartel DP. MicroRNAs: Genomics, biogenesis, mechanism, and function. Cell. 2004; 116(2): 281-297. 
7. Sevignani C, Calin GA, Siracusa LD, Croce CM. Mammalian microRNAs: A small world for fine-tuning gene expression. Mamm Genome. 2006; 17(3): 189-202.

8. Calin GA. MicroRNAs and cancer: What we know and what we still have to learn. Genome Med. 2009; 1(8): 78 .

9. Long QZ, Du YF, Liu XG, Li X, He DL. miR-124 represses FZD5 to attenuate P-glycoprotein-mediated chemo-resistance in renal cell carcinoma. Tumour Biol. 2015; 36(9): 7017-7026.

10. Xu Q, Krause M, Samoylenko A, Vainio S. Wnt signaling in renal cell carcinoma. Cancers (Basel). 2016; 8(6): 57.

11. Furuta M, Kozaki KI, Tanaka S, Arii S, Imoto I, Inazawa J. miR-124 and miR-203 are epigenetically silenced tumor-suppressive microRNAs in hepatocellular carcinoma. Carcinogenesis. 2010; 31(5): 766-776.

12. An L, Liu Y, Wu A, Guan Y. microRNA-124 inhibits migration and invasion by down-regulating ROCK1 in glioma. PLoS One. 2013; 8(7): e69478.

13. Livak KJ, Schmittgen TD. Analysis of relative gene expression data using real-time quantitative PCR and the 2(-Delta Delta C(T)) method. Methods. 2001; 25(4): 402-408.

14. Butz H, Szabó PM, Khella HW, Nofech-Mozes R, Patocs A, Yousef GM. miRNA-target network reveals miR-124as a key miRNA contributing to clear cell renal cell carcinoma aggressive behaviour by targeting CAV1 and FLOT1. Oncotarget. 2015; 6(14): 12543-12557.
15. Gebauer K, Peters I, Dubrowinskaja N, Hennenlotter J, Abbas M, Scherer R, et al. Hsa-mir-124-3 CpG island methylation is associated with advanced tumours and disease recurrence of patients with clear cell renal cell carcinoma. Br J Cancer. 2013; 108(1): 131-138.

16. Sõber S, Laan M, Annilo T. MicroRNAs miR-124 and miR-135a are potential regulators of the mineralocorticoid receptor gene (NR3C2) expression. Biochem Biophys Res Commun. 2010; 391(1): 727-732.

17. Zell S, Schmitt R, Witting S, Kreipe HH, Hussein $\mathrm{K}$, Becker JU. Hypoxia induces mesenchymal gene expression in renal tubular epithelial cells: An in vitro model of kidney transplant fibrosis. Nephron Extra. 2013; 3(1): 50-58.

18. Peng XH, Huang HR, Lu J, Liu X, Zhao FP, Zhang $\mathrm{B}$, et al. MiR-124 suppresses tumor growth and metastasis by targeting Foxq1 in nasopharyngeal carcinoma. Mol Cancer. 2014; 13: 186.

19. Li L, Luo J, Wang B, Wang D, Xie X, Yuan L, et al. Microrna-124 targets flotillin-1 to regulate proliferation and migration in breast cancer. Mol Cancer. 2013: 12: 163.

20. Li KK, Pang JC, Ching AK, Wong CK, Kong X, Wang Y, et al. miR-124 is frequently down-regulated in medulloblastoma and is a negative regulator of SLC16A1. Hum Pathol. 2009; 40(9): 1234-1243.

21. Shi Z, Chen Q, Li C, Wang L, Qian X, Jiang C, et al. MiR-124 governs glioma growth and angiogenesis and enhances chemosensitivity by targeting R-Ras and N-Ras. Neuro Oncol. 2014; 16(10): 1341-1353. 